\title{
Efek Sumber Karbon Berbeda terhadap Produksi â-Glukan oleh Saccharomyces Cerevisiae pada Fermentor Air Lift
}

\author{
Kusmiati*), Ahmad Thontowi, dan Sukma Nuswantara \\ Pusat Penelitian Bioteknologi-LIPI, Jalan Raya Bogor Km 46, Cibinong Bogor 16911 \\ Diterima 28-01-2010 Disetujui 26-11-2010
}

\begin{abstract}
ABSTRAK
The need of â-glucan is increasing in food, medicine and cosmetic industry, because it becomes anticancer, antitumor and antiaging, increases immunosystem, and decreases cholesterol content in blood. The cell walls of S. cerevisiae contain $\mathbf{8 0 - 9 0 \% ~ p o l y s a c c h a r i d e s ~ t h a t ~ p o s s e s ~ a ̂ - g l u c a n . ~ T h i s ~ r e s e a r c h ~ w a s ~ a i m e d ~ t o ~ o b t a i n ~ a p p r o p r i a t e ~}$ carbon sources to increase the production of â-glucan. The carbon sources used were glucose, glucose commercial, sucrose and molases. The fermentation process was done by using air lift fermentor. The steps of fermentaton included regeneration of $S$. cerevisiae strain, preculture, fermentor preparation and running fermentor for 84 hours. Sampling of $S$. cerevisiae culture was determined the cell growth by optical density (OD) using spectrophotometer UV/VIS at ë $550 \mathrm{~nm}$. The protein content was determined by Lowry method at ë $755 \mathrm{~nm}$ and the total glucose was measured by phenol sulphate method at ë $490 \mathrm{~nm}$. The measurement result of cell growth showed that the high intensity of $S$. cerevisiae in medium contain molases, but it did not show significant effect when compare to other carbon sources. The protein and carbohydrate contain in medium tended to decrease. The result of â-glucan on glucose, sucrose, glucose commercial and molases were 933,3, 1100, 1000, and $966,7 \mathrm{mg} / \mathrm{l}$. It can be concluded that sucrose and glucose commercial can replace the glucose to produce of âglucan, because they are cheaper and easier to get. Beside that, molases can be used as an alternative carbon source because it can produce of â-glucan as well as glucose.
\end{abstract}

Keywords: air lift fermentor, â-glucan, carbon sources, S. cerevisiae

\section{PENDAHULUAN}

$\beta$-Glukan merupakan polimer yang tersusun dari monomer glukosa. Senyawa ini banyak ditemukan pada dinding sel khamir dan dalam jumlah yang lebih kecil dijumpai pada gandum, ganggang laut, jamur dan tanaman lainnya. Senyawa $\beta$-glukan banyak mendapat perhatian karena banyak manfaatnya untuk kehidupan manusia, di antaranya untuk meningkatkan kekebalan tubuh, mencegah bakteri dan infeksi viral, serta aktivitas antitumor, immunomodulator, antikanker, dan bahan kosmetik (Lee et al., 2001; Kulicke et al., 1996). Sebagai bahan kosmetik, $\beta$-glukan mampu berperan untuk perbaikan sel-sel kulit yang rusak akibat paparan sinar ultraviolet yang berasal dari sengatan matahari dalam waktu panjang. Selain itu $\beta$-glukan disinyalir mampu untuk meregenerasi kandungan kolagen dan elastin untuk menjaga kelembaban dan kelenturan. âglukan juga dapat mencegah radikal bebas. â-Glukan melindungi makrofag dari serangan radikal bebas selama dan sesudah radiasi sehingga dapat digunakan sebagai antikanker.

\footnotetext{
*Telp: +628129506580

Email: kusmiati02@yahoo.com
}

Tubuh manusia dapat bertoleransi dengan baik dalam mengkonsumsi 15 gram â-glukan setiap harinya, 60 kali dari dosis yang dianjurkan selama 12 minggu tanpa menimbulkan efek negatif (Anonim, 2003). Blaylock (2002) menyatakan bahwa sumber â-1,3glukan yang paling efektif adalah berasal dari $S$. cerevisiae. S. cerevisiae telah dimasukkan dalam kategori GRAS (Generally Recognized As Safe) oleh Food and Drug Administration (FDA) di USA, sehingga aman digunakan dan dikonsumsi manusia. $S$. cerevisiae merupakan khamir yang mampu memproduksi â-glukan.

Dalam proses fermentasi kebutuhan nutrisi sangat penting untuk pertumbuhan mikroorganisme, sehingga perlakuan sumber karbon dan sumber nitrogen sangat mempengaruhi terhadap proses tersebut. Sumber karbon merupakan sumber energi yang dibutuhkan mikroorganisme untuk pertumbuhannya, sedangkan sumber nitrogen sangat dibutuhkan untuk sintesis protein. Pada umumnya sumber karbon yang digunakan pada proses fermentasi berupa monosakarida seperti glukosa dan disakarida seperti sukrosa dan laktosa. 
Namun untuk produksi skala industri dicari alternatif menggunakan sumber karbon yang murah dan mudah didapatkan. Selain itu sumber karbon yang dipilih harus menghasilkan produk yang berkualitas tinggi. Pemanfaatan limbah sisa produksi gula tebu seperti molase merupakan salah satu sumber karbon yang telah banyak dikembangkan dewasa ini.

Fermentor merupakan tempat berlangsungnya proses fermentasi. Pada penelitian ini produksi â-glukan oleh $S$. cerevisiae dilakukan dengan menggunakan fermentor air lift berskala 2 I. Hasil penelitian Lee et al., (2001) menunjukkan bahwa kualitas biopolimer dengan menggunakan fermentor bubble column lebih baik dibandingkan dengan menggunakan fermentor jar. Fermentasi dilakukan dalam tangki tertutup yang dilengkapi sistem aerasi dan agitasi. Dengan sistem ini fermentasi berlangsung relatif singkat dan terjaga dari kontaminasi (Rachman, 1989).

Dengan melihat begitu banyaknya manfaat yang dimiliki senyawa â-glukan yang dihasilkan oleh khamir S. cerevisiae ini, maka dilakukan penelitian yang bertujuan untuk meningkatkan produksi senyawa tersebut. Salah satu upaya yang dilakukan untuk menekan biaya produksi â-glukan yaitu dengan mencari sumber karbon yang tepat bagi pertumbuhan $S$. cerevisiae, mudah didapat dan lebih murah. Beberapa sumber karbon yang digunakan yaitu glukosa, sukrosa, gula pasir, dan molase. Parameter yang diukur selama proses fermentasi $S$. cerevisiae meliputi pertumbuhan sel S. cerevisiae, produksi â glukan dan analisis kandungan karbohidrat serta protein.

\section{BAHAN DAN METODE}

Konfirmasi S. cerevisiae secara mikroskopik. Saccharomyces cerevisiae berumur 48 jam dalam media YPG cair dioleskan pada kaca obyek, difiksasi dan diteteskan pewarna safranin, diratakan dan didiamkan beberapa saat. Olesan dibilas air steril dan diamati di bawah mikroskop dengan perbesaran 1000x.

Prakultur S. Cerevisiae. Stok kultur segar diinokulasikan ke dalam $5 \mathrm{ml}$ medium YPG cair, dikocok selama 24 jam pada suhu $28^{\circ} \mathrm{C}$, selanjutnya diinokulasikan sebanyak $2 \%$ ke dalam $100 \mathrm{ml}$ medium yeast pepton (YP) pada erlenmeyer sebagai prakultur. Kultur dikocok selama 48 jam pada suhu $28^{\circ} \mathrm{C}$.

Produksi â-Glukan dari S. cerevisiae. Media produksi. Komposisi media produksi untuk fermentasi S.cerevisiae yaitu: ekstrak khamir $1 \%$, sumber carbon
(C) $2 \%$, pepton $2 \%$ yang dilarutkan dalam air suling sebanyak $1900 \mathrm{ml}$. Sumber C divariasikan sebagai perlakuan menggunakan glukosa, molase, sukrosa dan gula pasir komersil. Prekultur S. cerevisiae segar diinokulasikan ke dalam medium produksi secara aseptis dengan menggunakan pompa peristaltik. Inkubasi dilakukan pada suhu $28^{\circ} \mathrm{C}$ selama 4 hari.

Preparasi fermentor. Fermentor dirancang sedemikian rupa sehingga dapat disterilkan dengan uap bertekanan. Medium fermentasi disterilkan beramasama di dalam fermentor. Dalam proses fermentasi aerobik dibutuhkan udara steril dalam jumlah besar, dan sterilisasi terhadap udara pada umumnya dilakukan dengan menggunakan penyaring berserat yang steril. Aerasi yang digunakan pada fermentasi ini sebesar $1,5 \mathrm{vvm}$. Aerasi dilakukan untuk mensuspensikan dan meratakan nutrisi dalam medium, memberikan oksigen bagi sel, dan untuk pemindahan panas.

Parameter yang diamati. Pertumbuhan $S$. cerevisiae dengan menggunakan metode $O D$. Pertumbuhan S. cerevisiae diamati dengan melakukan pengambilan sampel setiap 2 jam selama 24 jam, kemudian setiap 4 jam hingga jam ke-48, dan setiap 12 jam hingga jam ke-84. Pengukuran menggunakan Spektrofotometer UV/VIS pada ë $550 \mathrm{~nm}$.

Kadar karbohidrat. Analisis karbohidrat dilakukan dengan menggunakan metode fenol sulfat (Chaplin, 1986). Pengambilan sampel dilakukan setiap 2 jam selama 24 jam, kemudian setiap 4 jam hingga jam ke48, dan setiap 12 jam hingga jam ke-84. Deret larutan baku glukosa dibuat dengan konsentrasi: 0, 10, 20, 30, 40, 50, 60, 70, 80 dan 90 ppm. Sampel kultur disentrifugasi pada kecepatan 5000 rpm selama 15 menit dan diambil supernatannya. Supernatan dan larutan baku masing-masing sebanyak $1 \mathrm{ml}$ ditambahkan 0,5 ml larutan fenol 5\%, kemudian dikocok hingga homogen. Selanjutnya sampel dan larutan baku ditambahkan $2,5 \mathrm{ml}$ larutan $\mathrm{H}_{2} \mathrm{SO}_{4}$ pekat dan didiamkan selama 10 menit dan dididihkan pada suhu $100^{\circ} \mathrm{C}$ selama 15 menit, kemudian didinginkan selama 10 menit. Serapan diukur dengan Spektrofotometer UV/ VIS pada ë $490 \mathrm{~nm}$.

Anallisis protein dilakukan dengan metode Lowry (Plummer, 1979). Pengambilan sampel dilakukan setiap 2 jam selama 24 jam, kemudian setiap 4 jam hingga jam ke-48, dan setiap 12 jam hingga jam ke-84.

Deret larutan baku protein dibuat dengan menggunakan Bovine Serum Albumin (BSA) dengan 
konsentrasi: 0, 20, 40, 60, 80, 100, 120, 140, 160, 180 , 200, 250, 300, 350, 400, 450 dan 500 ppm. Sampel kultur disentrifugasi pada kecepatan 5000 rpm selama 15 menit dan diambil supernatannya. Supernatan dan larutan baku masing-masing sebanyak $0,5 \mathrm{ml}$ ditambahkan $0,5 \mathrm{ml}$ larutan $\mathrm{NaOH} 1 \mathrm{~N}$ dan dikocok homogen. Selanjutnya larutan dididihkan selama 20 menit pada suhu $100^{\circ} \mathrm{C}$, didinginkan pada suhu kamar, kemudian ditambahkan 2,5 mL larutan D (campuran $\mathrm{Na}_{2} \mathrm{CO}_{3} 2 \% \mathrm{~b} / \mathrm{v}, \mathrm{CuSO}_{4} \cdot 5 \mathrm{H}_{2} \mathrm{O} 1 \% \mathrm{~b} / \mathrm{v}$ dan K$\mathrm{Na}$ Tartrat $1 \% \mathrm{~b} / \mathrm{v})$. Larutan dikocok homogen lalu diamkan selama 10 menit, ditambahkan 0,5 ml pereaksi Follin C, diamkan 30 menit. Serapannya diukur dengan menggunakan Spektrofotometer UV/VIS pada ë $755 \mathrm{~nm}$.

Ekstraksi â-glukan. Ekstraksi â-glukan dilakukan menurut metode Lee et al., (2001). Pengambilan sampel untuk â-glukan dilakukan setiap 4 jam selama 48 jam, dan setiap 12 jam hingga jam ke-84. Sebanyak $30 \mathrm{ml}$ kultur disentrifugasi selama 20 menit dengan kecepatan $7000 \mathrm{rpm}$ dan suhu $15^{\circ} \mathrm{C}$. Supernatan dibuang, dan biomassa ditambahkan $\mathrm{NaOH} 2 \%$ lalu dipanaskan selam 5 jam pada suhu $90^{\circ} \mathrm{C}$. Kemudian disentrifugasi kembali selama 10 menit dengan kecepatan 5000 rpm. Supernatan yang didapat ditambahkan dengan asam asetat $2 \mathrm{M}$ untuk mengatur $\mathrm{pH}$ menjadi sekitar 6,8-7,0. Kemudian ditambahkan etanol, lalu dipresipitasikan. Setelah presipitasi, dilakukan sentrifugasi lagi selama 10 menit dengan kecepatan 5000 rpm. Endapan yang didapat dikeringkan dalam oven vakum dan ditimbang beratnya.

\section{HASIL DAN PEMBAHASAN}

Morfologi sel S. Cerevisiae. Pengamatan sel $S$. cerevisiae dilakukan secara mikroskopik dengan pewarnaan sederhana menggunakan pewarna safranin. Pengamatan dilakukan untuk memastikan bahwa khamir yang akan digunakan tidak terkontaminasi oleh mikroorganisme lain. Berdasarkan hasil pengamatan di bawah mikroskop dengan perbesaran 1.000x, terlihat bentuk morfologi $S$. cerevisiae sebagai berikut: sel berbentuk oval, berbau roti dan koloninya agak berlendir. Pertumbuhannya membutuhkan oksigen, sangat kecil dipengaruhi oleh perubahan $\mathrm{pH}$, suhu optimum untuk tumbuh antara $22-30^{\circ} \mathrm{C}$ dan toleran hingga $37^{\circ} \mathrm{C}$ (Barnet, 1990).

Pengukuran pertumbuhan sel $\boldsymbol{S}$. Cerevisiae. Proses fermentasi S.cerevisiae dilakukan dengan menggunakan sumber karbon yang berbeda yaitu glukosa, sukrosa, gula pasir komersil, dan molase untuk memproduksi â-glukan.

Pertumbuhan sel dengan menggunakan sumber karbon berbeda hingga 64 jam tidak menunjukkan perbedaan yang nyata, tetapi pada pengamatan 84 jam molase menunjukkan pertumbuhan sel yang lebih tinggi dibandingkan menggunakan sumber karbon lainnya (Gambar 1). Fermentasi dilakukan sampai jam ke-84 karena pada hari ke-3 sel akan memasuki fase stasioner dan menuju fase kematian, pada fase kematian adanya akumulasi autotoksin dan metabolit penghambat pertumbuhan menyebabkan kualitas â-glukan yang dihasilkan sudah tidak baik lagi. Oleh karena itu fermentasi hanya dilakukan hingga jam ke-84. Selain itu berdasarkan penelitian pendahuluan yang dilakukan setelah melewati jam ke-84 sudah tidak menunjukkan peningkatan yang nyata terhadap produksi â-glukan.

Produksi â-glukan pada media mengandung sumber karbon glukosa. Glukosa merupakan monosakarida yang sangat umum digunakan sebagai sumber karbon dalam medium fermentasi. Pertumbuhan sel dengan menggunakan sumber karbon glukosa memasuki fase eksponensial pada jam ke-4 hingga jam ke-22 (Gambar 2).

Fase eksponensial pada kultur tertutup relatif lebih pendek karena adanya penurunan nutrisi yang esensial, akumulasi metabolit penghambat pertumbuhan dan kelebihan sel yang terflokulasi (Walker, 1995). Setelah jam ke-22 sel memasuki fase stasioner dan pertumbuhan sel mulai konstan. Pada jam ke-36 terjadi kenaikan yang cukup tinggi yaitu pertumbuhan sel mencapai OD 4,995 yang kemudian mengalami penurunan kembali. Hal ini disebabkan pada saat pengambilan sampel, kultur sel yang diambil mungkin kurang homogen.

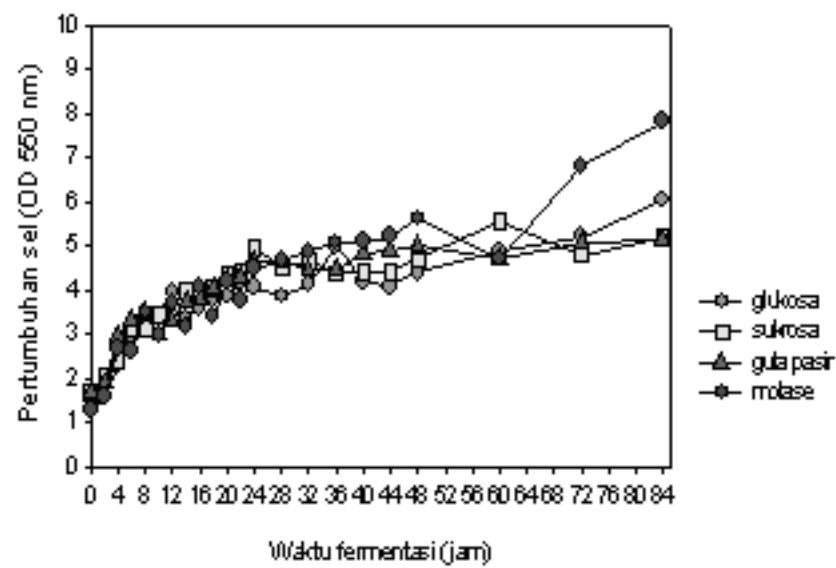

Gambar 1. Kurva pertumbuhan sel $S$. cerevisiae pada media dengan sumber karbon berbeda 


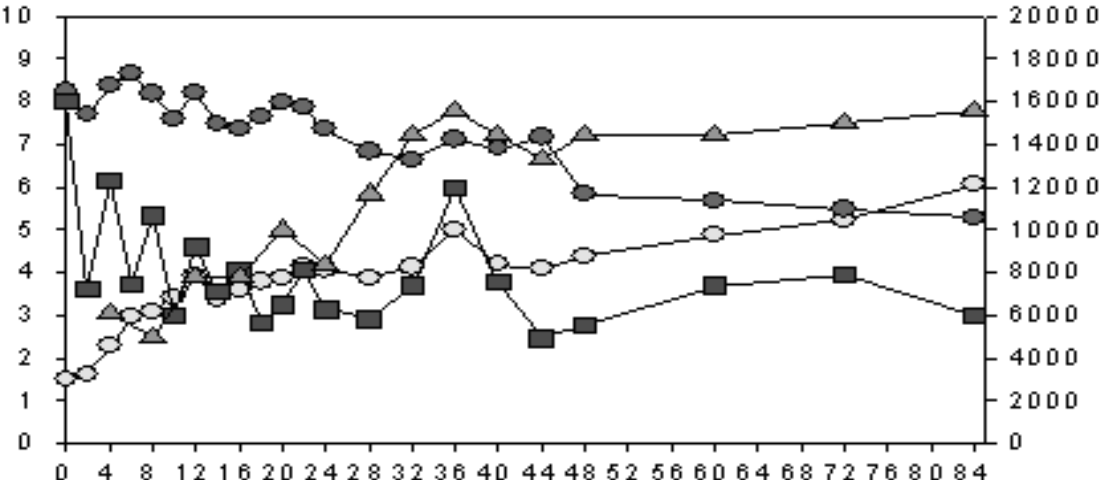

Produksi â-glukan dengan menggunakan sumber karbon glukosa menunjukkan kenaikan hingga jam ke84. Dilaporkan bahwa S. cerevisiae dapat tumbuh baik dalam media mengandung glukosa dengan konsentrasi 50-100mM (Barnet, 1990). Pada jam ke-4 â-glukan yang dihasilkan sebesar 366,7 mg/l dan pada jam ke-84 âglukan yang dihasilkan sebesar 933,3 mg/l. Kenaikan ini terjadi seiring dengan bertambahnya jumlah sel. Pembentukan â-glukan akan terus berlangsung dan meningkat hingga mencapai fase pertumbuhan stasioner (Kusmiati \& Nuswantara, 2006).

Kandungan karbohidrat pada media mengandung glukosa terjadi penurunan yang sangat tajam hingga jam ke-2. Kemudian pada jam ke-4 hingga jam ke-44 kandungan karbohidrat dalam media mengalami kenaikan dan penurunan yang cukup fluktuatif.

Pada jam ke-48 kandungan karbohidrat meningkat kemudian mulai mengalami penurunan secara bertahap hingga jam ke-84. Kandungan protein dalam media mulai terjadi penurunan pada jam ke-44 hingga jam ke84. Hal ini disebabkan pada fase pertumbuhan stasioner populasi mencapai maksimum dan tidak bertambah lagi, namun populasi masih aktif secara metabolik untuk memproduksi metabolit sekunder (Standbury \& Whitaker, 1984). Penurunan kadar protein pada fase stasioner karena pembentukannya berkurang, sementara yang telah terbentuk digunakan untuk pertumbuhan biomasa sel untuk menyusun dinding sel dan aktifitas metabolisme lainnya.

Penentuan konsentrasi protein di dalam medium fermentasi dilakukan menggunakan metode Lowry. Metode Lowry lebih sensitif dari pada metode Biuret dan memiliki daerah analisis dari $10 \mu \mathrm{g}-1.0 \mathrm{mg}$ protein . Metode ini berdasarkan reaksi Biuret dimana ikatan peptida (CO-NH) pada protein bereaksi dengan $\mathrm{Cu}^{2+}$ dibawah kondisi alkali menghasilkan $\mathrm{Cu}^{+}$. Kemudian $\mathrm{Cu}^{+}$bereaksi dengan Follin-Ciocalteau yang merupakan campuran natrium tungstat, molibdat, dan fosfat menyebabkan reduksi phospomolibdotungstat menjadi heteropolimolibdenum biru. Intensitas warna biru yang dihasilkan dipengaruhi oleh kandungan tirosin dan triptofan di dalam sampel protein. Standar penentuan konsentrasi protein menggunakan larutan BSA (Bovine Serum Albumin) karena mempunyai kemurnian yang tinggi dan mudah didapatkan (Wilson \& Walker, 2000).

Produksi â-glukan pada media mengandung sumber karbon sucrosa. Pertumbuhan sel menggunakan sumber karbon sukrosa menunjukkan bahwa sel mengalami fase eksponensial hingga jam ke-22 (Gambar 3) dan selanjutnya sel memasuki fase stasioner hingga jam ke-84.

Sukrosa merupakan disakarida yang terdiri atas glukosa dan fruktosa. Sukrosa sebagai substrat dihidrolisis oleh $S$. cerevisiae menggunakan enzim invertase (â-D-fruktofuranosidase) (Dynesen et al., 1998). Glukosa dan fruktosa yang dihasilkan masuk ke dalam sel oleh enzim permease yang terdapat di dalam membran.

Hasil ekstraksi â-glukan dengan menggunakan sumber karbon sukrosa memberikan hasil sebesar $333,3 \mathrm{mg} / \mathrm{l}$ pada jam ke-4, seiring dengan pertumbuhan sel terjadi peningkatan mencapai $1100 \mathrm{mg} / \mathrm{l}$ hingga jam ke-84. Pada jam ke-24, 28, 36, 40, 44 dan 60 terjadi penurunan pada produksi â-glukan yang menyebabkan grafik tampak fluktuatif (Gambar 3). Penurunan ini dapat disebabkan oleh adanya endapan-endapan yang ikut terbuang selama proses ekstraksi. Produksi â-glukan dengan sumber karbon sukrosa lebih tinggi jika dibandingkan dengan sumber karbon glukosa yang hanya mencapai 933,3 mg/l. Lee (1997) melaporkan 
bahwa sukrosa merupakan sumber karbon yang paling efisien untuk produksi â-glukan. Hal ini disebabkan proses fermentasi sukrosa melalui hidrolisis ekstraseluler dengan perantara invertase periplasmik menghasilkan glukosa dan fruktosa yang akan ditrasportasi untuk sel dan proses metabolisme menghasilkan produk (Anderson et al., 2004).

Pada media dengan sumber karbon sukrosa penurunan kandungan karbohidrat terjadi hingga jam ke-8, selanjutnya pada jam ke-10 sampai jam ke-44 kandungan karbohidrat cenderung fluktuatif dan mulai mengalami penurunan lagi pada jam ke-48 hingga jam ke-84. Kandungan protein mulai mengalami penurunan pada jam ke-48 hingga jam ke-84. Sumber nitrogen di dalam media fermentasi digunakan untuk sintesis protein di dalam sel. Adanya penyerapan sel terhadap sumber nitrogen ini menyebabkan kandungan protein di dalam media semakin berkurang dengan lamanya waktu fermentasi.

Produksi â-glukan pada media mengandung sumber karbon gula pasir komersil. Gula pasir banyak digunakan dalam kehidupan manusia sehari- hari. Selain mudah didapatkan, gula pasir merupakan karbohidrat yang lebih murah harganya dibandingkan karbohidrat lainnya.

Pertumbuhan sel menggunakan sumber karbon gula pasir komersil (Gambar 4) menunjukkan bahwa sel sempat mengalami fase adaptasi pada jam ke-0 dan jam ke-2, pada fase ini pertumbuhan sel tidak mengalami peningkatan yang cukup berarti. Bila suatu kultur mikroba akan dipindah dari satu lingkungan ke lingkungan lainnya, maka perlu diketahui komponenkomponen lingkungan tersebut lebih dahulu melalui proses adaptasi. Setelah fase adaptasi (fase lag) selesai, mikroba memasuki fase pertumbuhan eksponensial (fase log) yaitu fase pada saat pertumbuhan berlangsung konstan dengan laju pertumbuhan maksimum. Pada percobaan ini kultur sel memasuki jam ke-4 sampai sekitar jam ke-22, pertumbuhan sel berada pada fase eksponensial. Laju pertumbuhan maksimum berbeda-beda tergantung pada spesies mikroba dan kondisi kultur. Laju pertumbuhan maksimum juga dipengaruhi oleh panjang rantai molekul substrat, karena untuk memecah substrat dengan rantai

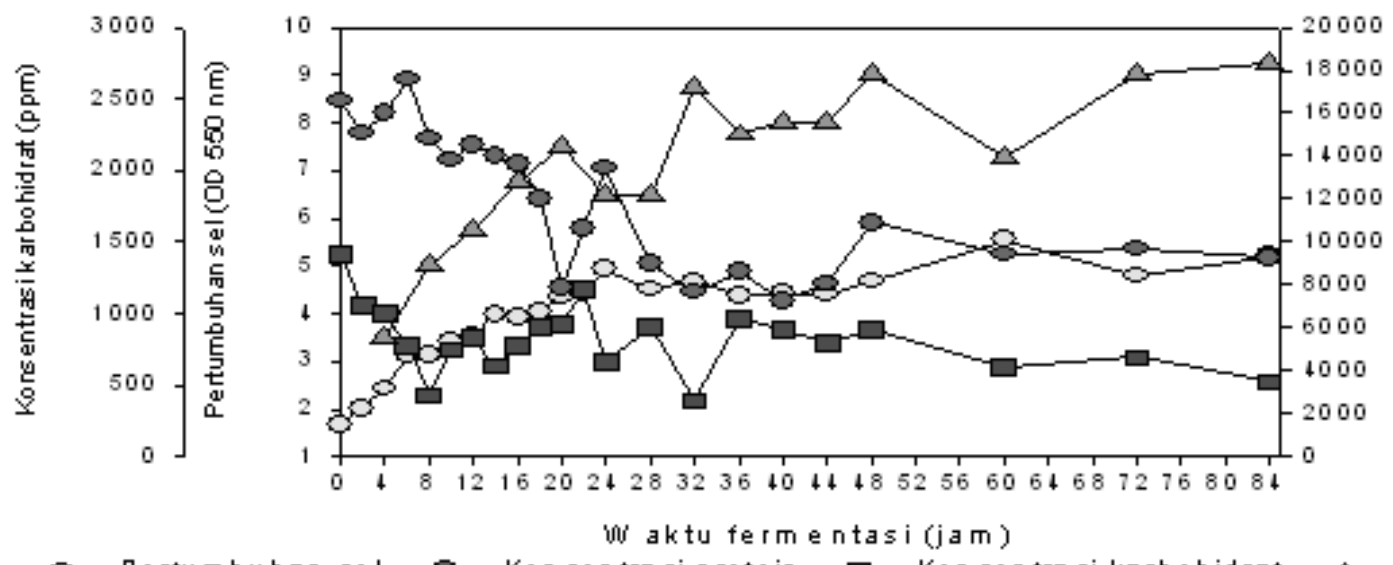

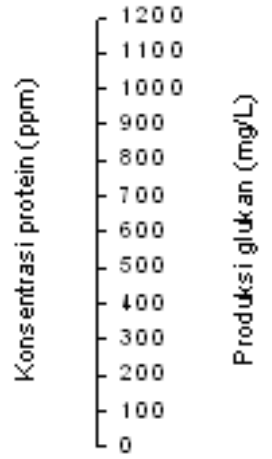

Gambar 3. Produksi â-glukan oleh S. cerevisiae dan hasil analisis kimia pada media mengandung sukrosa
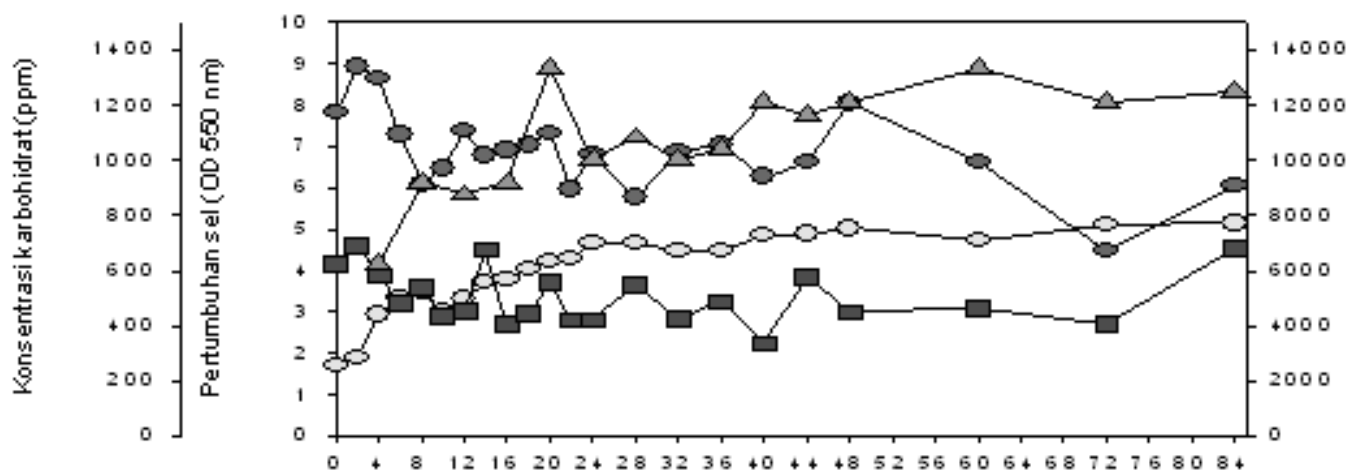

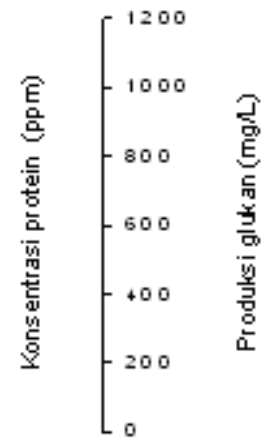

ivi aktu fermentasi (jam)

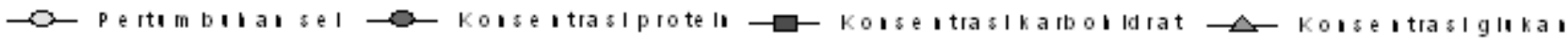
Gambar 4. Produksi â-glukan oleh S. cerevisiae dan hasil analisis kimia pada media mengandung gula pasir 
molekul yang lebih panjang dibutuhkan energi yang lebih besar. Setelah jam ke-22 sel memasuki fase stasioner. Pada fase stasioner aktifitas metabolisme sel masih berlangsung dan mikroba memproduksi metabolit sekunder, fase stasioner merupakan fase populasi maksimum.

Produksi â-glukan menggunakan sumber karbon gula pasir komersil pada awal pengambilan sampel yaitu jam ke-4 menunjukkan hasil yang lebih tinggi sebesar $500,0 \mathrm{mg} / \mathrm{l}$ dibandingkan sumber karbon glukosa dan sukrosa yang masing-masing sebesar 366,7 dan 333,3 $\mathrm{mg} / \mathrm{l}$. Pada akhir pengambilan sampel yaitu jam ke-84 dihasilkan â-glukan sebesar 1000,0 mg/l, produk yang diperoleh lebih tinggi dibandingkan dengan menggunakan sumber karbon glukosa yang hanya mencapai 933,3 mg/l.

Kandungan karbohidrat pada media yang mengandung gula pasir komersil cenderung fluktuatif, ketika memasuki jam ke-44 kandungan karbohidrat mulai mengalami penurunan sedikit demi sedikit, tetapi pada jam ke-84 terjadi kenaikan yang cukup tajam yang mungkin disebabkan oleh beberapa hal diantaranya ketidak murnian produk komersil yang diperoleh di pasar sehingga mempengaruhi hasil analisis. Penurunan kandungan protein pada media dengan sumber karbon gula pasir komersil mulai terjadi pada jam ke-48, dan pada jam ke-84 terjadi kenaikan yang cukup tajam.

Produksi â-glukan pada media mengandung sumber karbon molase. Molase merupakan hasil samping dari pabrik gula tebu, berbentuk cairan berwarna coklat hitam dan merupakan sumber karbohidrat termurah, kaya akan gula, mengandung nitrogen, vitamin, dan elemen lainnya. Penggunaan molase sebagai sumber karbon dalam fermentasi karena adanya kandungan gula dan berbagai nutrisi yang diperlukan bagi mikroorganisme untuk tumbuh dan berkembang biak. Komposisi molase bervariasi tergantung pada bahan baku yang digunakan untuk produksi gula. Pada umumnya molase mengandung glukosa, fruktosa, dan sukrosa, selain itu trisakarida seperti rafinosa bisa juga terkandung di dalamnya sebesar $2 \%$ dari berat kering (Rosen, 1987).

Pertumbuhan sel dengan menggunakan sumber karbon molase cenderung lebih tinggi dibandingkan dengan sumber karbon lainnya (Gambar 5). Hal ini disebabkan kondisi fisiologi pertumbuhan sel lebih baik pada medium yang kaya, dalam hal ini molase mengandung senyawa bernitrogen, garam organik, vitamin dan elemen mikro yang mampu menstimulasi metabolisme sel (Compagno et al., 1992). Pada jam ke-0 hingga jam ke-2 sel masih mengalami fase adaptasi dengan lingkungan barunya, kemudian pada jam ke-4 hingga sekitar jam ke-22 sel memasuki fase eksponensial. Setelah itu sel berada pada fase stasioner hingga jam ke-84. Kenaikan dan penurunan pertumbuhan sel terjadi karena kultur kurang homogen saat pengambilan sampel dan menyebabkan grafik tampak fluktuatif, terutama pada jam ke-60 pada saat sel mengalami penurunan yang cukup tajam.

â-Glukan yang dihasilkan dengan menggunakan sumber karbon molase mengalami peningkatan dari sebesar 366,7 mg/l pada jam ke-4 hingga sebesar $966,7 \mathrm{mg} / \mathrm{l}$ pada jam ke-84. Penurunan hasil ekstraksi â-glukan terjadi pada jam ke-32 dan 34 , hal ini disebabkan kemungkinan adanya partikel endapan yang terbuang pada saat ekstraksi. Hasil ekstraksi âglukan dengan media molase tidak sebesar hasil
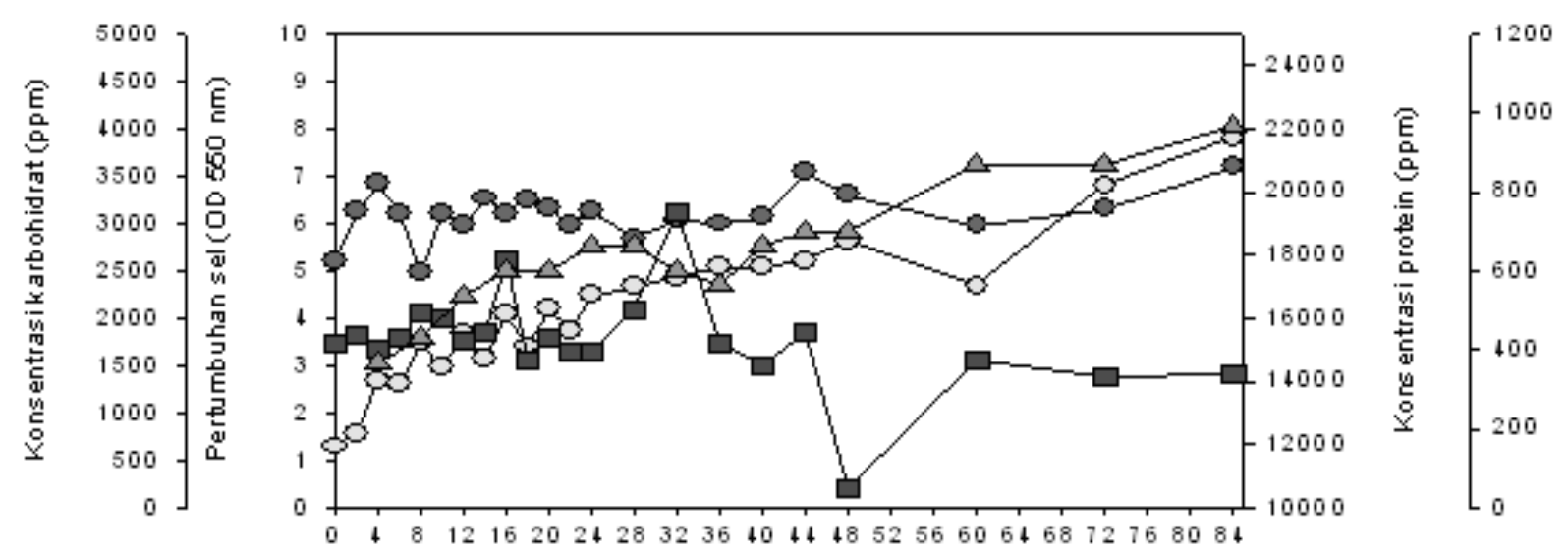

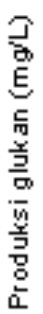

iol aktu fermentasi (jam)

$\rightarrow-$ Pertumbuhan sel $\rightarrow$ - Konsentrasi protein $\square-$ Konsentrasi karbohidrat $\triangle-$ Konsentrasiglukan Gambar 5. Produksi â-glukan oleh S. cerevisiae dan hasil analisis kimia pada media mengandung sumber karbon molase 
ekstraksi dengan media sukrosa dan gula pasir, tetapi masih lebih tinggi jika dibandingkan dengan media yang mengandung glukosa. Hal ini diduga bahwa sel $S$. cerevisiae membutuhkan proses untuk memanfaatkan molase yaitu melalui hidrolisis enzim invertase sehingga membentuk gula tersedia yaitu glukosa dan fruktosa (Compagno et al., 1992).

Media dengan sumber karbon molase memiliki pola kandungan karbohidrat yang serupa dengan sumber karbon lainnya, dan mulai mengalami penurunan pada jam ke-44 hingga jam ke-84. Kandungan protein dengan media mengandung molase cenderung fluktuatif dan tidak menunjukkan penurunan secara nyata bahkan mengalami kenaikan. Hal ini disebabkan oleh komposisi molase yang cukup kompleks sehingga mempengaruhi metabolisme sel tersebut.

Ekstraksi â-glukan dari S.cerevisiae. Produksi â-glukan dilakukan melalui proses ekstraksi dari dinding sel $S$. cerevisiae. Kultur yang diambil pada waktu-waktu tertentu sebagai sampel disentrifugasi untuk memisahkan sel dari mediumnya. Selanjutnya pelet sel ditambahkan larutan $\mathrm{NaOH} 2 \%$ karena âglukan dapat larut dengan baik dalam larutan alkali. Suspensi sel tersebut kemudian dipanaskan pada suhu $90^{\circ} \mathrm{C}$ selama 5 jam untuk memecah dinding sel $S$. cerevisiae sehingga â-glukan yang terdapat di dalam dinding sel dapat larut dalam larutan alkali tersebut. âGlukan yang didapatkan masih belum murni dan masih tercampur dengan kitin, protein dan mannan. Setelah larutan dipanaskan dilakukan sentrifugasi lagi. Penambahan asam asetat pada proses ekstraksi ini berfungsi untuk menetralkan $\mathrm{pH}$ dan melarutkan lipid, sedangkan penambahan etanol berfungsi untuk memperkecil kelarutan â-glukan dalam $\mathrm{NaOH}$ serta mempresipitasikan â-glukan sehingga didapatkan endapan â-glukan kasar (Lee et al., 2001). â-Glukan tersusun atas monomer-monomer glukosa yang saling berikatan membentuk suatu rantai panjang. Glukosa yang menjadi substrat bagi $S$. cerevisiae mula-mula akan memasuki sel melalui mekanisme transpor aktif. Kemudian sel akan memulai sintesis polisakaridanya dan menghasilkan â-glukan (Priest \& Campbell, 1996).

Pada Gambar 6 terlihat pola peningkatan produksi â-glukan dari $S$. cerevisiae yang seiring dengan meningkatnya jumlah sel. Produksi â-glukan tertinggi sebesar 1100,0 dan 1000 mg/l masing-masing dihasilkan oleh media yang mengandung sumber karbon sukrosa dan gula pasir. Sedangkan dengan menggunakan sumber karbon glukosa dan molase masing-masing dihasilkan â-glukan sebesar 933,3 dan $966,7 \mathrm{mg} / \mathrm{l}$. Data ini menunjukkan bahwa penggunaan sumber karbon gula pasir komersil dan sukrosa mampu menghasilkan â-glukan yang sama baiknya secara kuantitas dengan glukosa. Selain itu, gula pasir dan sukrosa relatif jauh lebih murah dan mudah didapatkan sehingga sangat menguntungkan untuk digunakan pada produksi â-glukan skala industri (Lee, 1997).

Sumber karbon molase juga dapat digunakan menjadi pengganti glukosa dengan melihat hasil produksi molase yang sebaik glukosa. Penggunaan molase sebagai sumber karbon sudah dilakukan sejak lama, karena molase merupakan produk samping yang murah dari industri gula dan sangat menarik bila dipandang dari segi ekonomi dan lingkungan karena merupakan pemanfaatan limbah industri (Lee, 1997). Pada produksi skala industri, pemilihan substrat merupakan parameter yang paling penting untuk mendapatkan keuntungan.

Hasil penelitian ini menunjukkan bahwa sumber karbon glukosa, sukrosa, gula pasir komersil, dan molase dapat digunakan untuk memproduksi â-glukan, dan untuk menentukan konsentrasi optimum dari masing-masing sumber karbon perlu dilakukan penelitian lebih lanjut.

Proses fermentasi untuk produksi â-glukan dilakukan dengan menggunakan fermentor air lift skala 2 I. Beberapa keunggulan fermentor air lift dibandingkan dengan fermentor lainnya yaitu tidak ada bagian yang bergerak di dalamnya, sederhana, mempunyai efisiensi absorpsi gas yang tinggi, serta memiliki perpindahan panas yang baik (Lee, 1992). Lee et al., (2005),

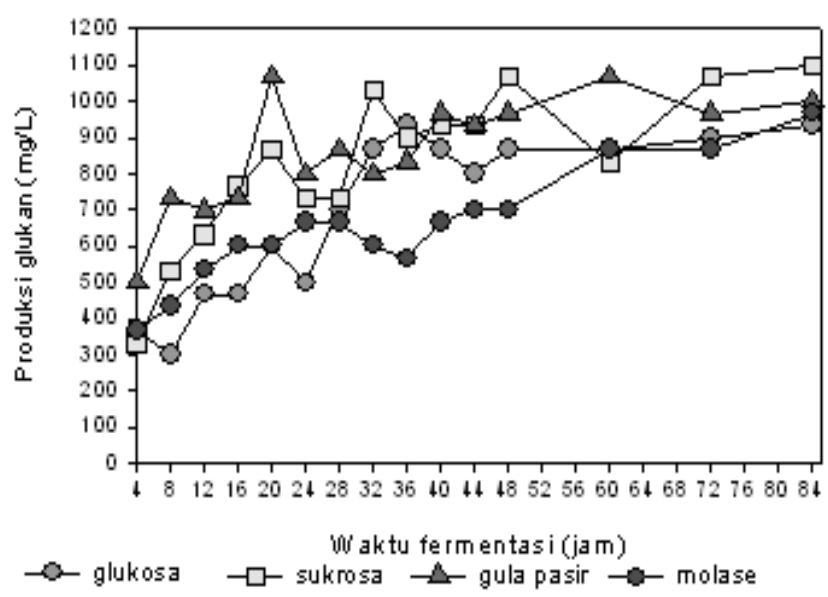

Gambar 6. Produksi â-glukan dari S. cerevisiae pada media dengan sumber karbon berbeda 
melakukan perbandingan produksi â-glukan dengan menggunakan fermentor jar (menggunakan pengadukan mekanis) dan fermentor bubble column (tanpa pengadukan mekanis). Hasil penelitiannya menunjukkan bahwa dengan menggunakan fermentor tanpa pengadukan mekanis kualitas biopolimer yang dihasilkan lebih baik dibandingkan dengan fermentor jaryang menggunakan pengadukan mekanis, meskipun jumlah produk â-glukan yang dihasilkan sedikit lebih tinggi dengan menggunakan fermentor jar. Oleh karena itu pada penelitian ini digunakan fermentor air lift (tanpa pengadukan mekanis) untuk memperoleh kualitas âglukan yang baik.

\section{KESIMPULAN}

Berdasarkan hasil yang diperoleh pada penelitian ini, maka dapat disimpulkan bahwa Glukosa, sukrosa, gula pasir komersil, dan molase dapat digunakan sebagai sumber karbon dalam medium fermentasi untuk memproduksi â-glukan.

Produksi â-glukan yang dihasilkan dengan menggunakan sumber karbon glukosa, sukrosa, gula pasir komersil, dan molase memberikan hasil tertinggi pada sumber karbon sukrosa yaitu sebesar 1100,0 mg/ I lalu diikuti dengan sumber karbon gula pasir komersil, molase, dan glukosa masing-masing sebesar 1000 , 966,7, dan 933,3 mg/l.

Hasil produksi â-glukan menunjukkan bahwa sukrosa dan gula pasir komersil dapat dipilih sebagai sumber karbon alternatif untuk produksi â-glukan. Molase sebagai limbah pabrik gula dapat pula dipertimbangkan mengingat molase mampu menghasilkan â-glukan sebaik glukosa.

\section{UCAPAN TERIMA KASIH}

Pada kesempatan ini penulis mengucapkan rasa terima kasih kepada Saudari Yenti atas bantuannya selama penelitian ini berlangsung.

\section{DAFTAR PUSTAKA}

Anderson, S.B., Luiz, C.M. \& Boris, U.S. 2004. Sucrose fermentation by $S$. cerevisiae lacking hexose transport. Journal Mol. Microbiol. Biotechnol 8: 26-33.

Anonim. 2003. Http://www.lifesourcebasics.com/safe.htm. Diakses tgl 22 April 2005.

Barnet, J.A.1990.Characteristic and identification yeast. New York: Cambridge University Press.

Blaylock, R.L. 2002. Yeast â-1,3-Glucan and its use against anthrax infection and in the treatment of cancer. JANA 5 (2).

Chaplin, M.F. 1986. Carbohydrate Analysis a Practical Approach. Oxford. England: IRL Press.

Compagno, C., Tura, A., Ranzi, B.M. \& Martegani, E. 1992. Production of fructose diphosphate by bioconversion of mollases with S. cerevisiae cells. Biotech. Letters 14(6): 495-498.

Dynesen, J., Smits, H.P., Olsson, L. \& Nielsen, J. 1998. Carbon catabolite repression of invertase during batch cultivations Saccharomyces cerevisiae: The role of glucose, fructose, and mannose. Journal Applied Microbiol Biotechnol 50: 579-582.

Kulicke, W.M., Lettau, Al. \& Thielking, H. 1996. Correlation Between Immunological Activity, Molar Mass, and Molecular Structure of Different (1,3)-â-D-Glucans.Carbohydrat Research 297: 135-143.

Kusmiati. \& Nuswantara, S. 2006. Pembentukan glukan oleh Saccharomyces $\mathrm{sp}$. pada media mengandung trimetroprim. Proseding seminar nasional Bioteknologi "Capturing opportunities through Biotechnology" Pusat Penelitian Bioteknologi-LIPI, Cibinong 15-16 Nopember 2006. 388-398.

Lee, I.Y. 1997. Curdlan.http://www.wileyvch.de/booksbiopoly/ pdfv05/bpol5006135144.pdf.

Lee, J.M., Lee, D.Y., Ji, I.H., Kim, G.E., Kim, H.M., Sohn, J. Kim, S. \& Kim, CW. 2001. Purification of soluble â-glucan with immune-enhancing activity from cell wall of yeast. Journal Bioscience. Biotechnology. Biochemistry 65(4): 837-841.

Lee, J.M. 1992. Biochemical Engineering. New Jersey: Prentice Hall, Englewood Cliffs.

Lee, M., Moon, C.J. Lee, J.H. 2005. Effect of fermentation condition on the curdlan Production.Http:// www.cape.canterbury.ac.nz/webdb/ApccheProceedings/ APCChE/Data/13/rev.pdf.

Plummer, D.T. 1979. An Introduction To Practical Biochemistry, $2^{\text {nd }}$ edition. New Delhi: Tata McGraw - Hill Publishing Company Ltd.

Priest, F.G., Campbell, I. 1996. Brewing Microbiology, $2^{\text {nd }}$ ED. London: Published Chapman and Hall.

Rachman, A. 1989. Pengantar Teknologi Fermentasi. Bogor, PAU IPB.

Rosen. 1987. Production of Baker's Yeast. In: Berry D. Russel I. Stewart GG, editors. Yeast Biotechnology. Part V London: Allen and Unwin. p 471-500.

Stanbury, P.F. \& Whitaker, A. 1984. Principles of Fermentation Technology. Oxford: Pergamon Press.

Walker, G.M. 1995. Yeast Physiology and Biotechnology. Chichester. John Wiley and sons.

Wilson, Keith. \& Walker, J. 2000. Principles and Techniques of Practical Biochemistry fifth edition. United Kingdom: Press Syndicate of The University of Cambridge. 